\title{
PYROLYSIS OF YAOJIE OIL SHALE IN A SANJIANG- TYPE PILOT-SCALE RETORT
}

\author{
YANYAN SHI ${ }^{(a)}$, SHUYUAN LI ${ }^{(b)^{*}}$, YUE MA ${ }^{(b)}$, CHANGTAO

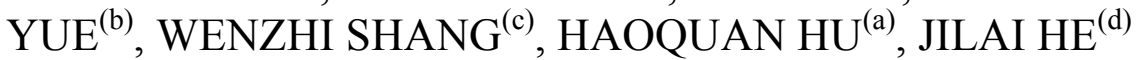

(a) Dalian University of Technology

Dalian, Liaoning 116024, China

(b) China University of Petroleum

Beijing 102249, China

(c) Sanjiang Coal Chemical Inc. Shenmu, Shaanxi 719300, China

(d) Shandong Energy Longkou Mining Group Co., Ltd Longkou, Shandong 265701, China

\begin{abstract}
In this paper, the basic principle and features of the process carried out in a Sanjiang(SJ)-type rectangular pilot-scale retort have been described. The suitability of the SJ retort for processing oil shale from Yaojie (YJ) county, Gansu province, China was investigated to find optimal conditions for an effective recovery of shale oil. The pyrolysis of lump YJ oil shale was carried out in the SJ pilot retort with a daily processing capacity of 24 tons of oil shale. It was found that the heat value of the pyrolysis gas produced from YJ oil shale was sufficient to provide the heat needed for retorting. The pyrolysis temperature fluctuated between 550 and $700{ }^{\circ} \mathrm{C}$, with an average of $610^{\circ} \mathrm{C}$. The results of the study demonstrate that the shale oil yield from YJ oil shale is high, accounting for about $85 \%$ vs. Fisher assay. The shale oil consists mainly of diesel and heavy fractions, and the spent shale is of high calorific value.
\end{abstract}

Keywords: pyrolysis, oil shale, shale oil, pilot-scale, SJ-type retort.

\section{Introduction}

Crude oil is an important feedstock for the petrochemical industry and the dominant source of energy driving the world economy. But at the current rate of production and consumption the known reserves of oil will be able to meet the ever-growing demand for energy for no longer than 50 years. Oil shale, a fine-grained sedimentary rock, contains a proportionally high

\footnotetext{
*Corresponding author: e-mail syli@cup.edu.cn
} 
amount of organic material called kerogen, and a little bitumen, which can be converted to oil by thermal degradation. Among alternative energy sources, oil shale appears to be particularly attractive because of its large deposits distributed throughout the world. The most abundant oil shale reserves are located in the United States. Significant oil shale resources are also deposited in other countries, such as China, Russia, Brazil, Morocco, Jordan, Australia, Estonia and Canada.

In recent years, due to the ever-increasing demand for crude oil and rise of its price, more attention has been paid to oil shale resources in China, with a view to producing shale oil [1-2].

China possesses abundant resources of oil shale, its reserves being about 31.57 billion tons. Oil shale is mainly distributed in Huadian and Nongan of Jilin province, Fushun of Liaoning province and Maoming of Guangdong province, all China. Retorting for producing shale oil and burning for generating power are the main modes of its utilization [3-4]. At present, China employs a Fushun-type retort for the commercial retorting of lump oil shale. This retort is a vertical cylindrical vessel, incorporating an upper section for oil shale drying and pyrolysis, and a lower section for shale char gasification and combustion. The heat required for pyrolysis is provided from two sources: i.e. the hot gas produced from the gasification and combustion of shale char with an air blast, and the hot recycle pyrolysis gas from a recuperator entering the middle part of the retort. The Fushun-type retort is suitable for retorting only lean oil shale, whose pyrolysis gas is unable to supply sufficient heat for retorting. The daily capacity of the retort is merely 100 tons of oil shale, and its shale oil yield is but $65-70 \%$ vs. Fischer Assay [5-8].

Compared with the Fushun retort, the SJ-type pilot-scale retort enables higher oil yield to be obtained and also its daily capacity is higher. This means that oil shale resources are utilized in a more efficient way, which eventually leads to higher total profit [9]. This paper describes the basic principle and features of the pyrolysis process carried out in the SJ-type pilot-scale retort. It also considers the behaviour of $\mathrm{YJ}$ oil shale during pyrolysis in the retort. The SJ-type pilot retort's capacity is 24 tons of oil shale per day, making one tenth of the commercial size.

\section{Features of the SJ-type retort}

The process carried out in the SJ-type retort represents an aboveground retorting method for obtaining shale oil from oil shale. It takes its name from the developer, the Sanjiang Coal Chemical Inc. (SJ Company), which is located in Shenmu, Shaanxi province, northwestern China. In 2000, SJ Company started to develop an appropriate technology for processing bituminous coal in Shenmu. With the improvement of the rectangular gas 
combustion retort for oil shale processing in Maoming [3], SJ Company developed an SJ-type retort [4].

It should be noted that the gas combustion retort is suitable for processing relatively rich oil shale, whose pyrolysis gas can provide sufficient heat required for the pyrolysis of oil shale.

The SJ retort uses a technology, which consists, as an advantage, in its uniform gas distribution system, and in pushing the coke to and cooling it at the bottom of the retort. The specially designed tar condensing facility includes a first condenser, a Venturi tube, a second condenser, a swirling tray tower, and an electrostatic precipitator.

The SJ retort has further advantages, such as high thermal efficiency, high oil yield ( $80 \%$ of Fischer Assay), simple design, high operational flexibility, as well as low investment costs. The retort consists of the upper drying section, the middle pyrolysis section and the lower coke cooling section. The mined coal is transported to a crusher where it is ground to the lump size of $12-100 \mathrm{~mm}$. Then the material is transported on a belt to the top of the retort. Coal is fed to the retort where it is subjected to low-temperature drying and high-temperature retorting. The circulating retorting gas, introduced to the middle part of the retort, is used to supply heat for retorting. Thereafter the organic matter is released from coal as oil vapor and retorting gas. In the next stage, coke is cooled at the bottom of the retort.

100,000 tons of coal is processed in each SJ retort per year. The process generates 60,000 tons of char and about 10,000 tons of coal tar. The commercial SJ retort, with a daily capacity of 250 tons of coal, is a rectangular vertical brick-lined steel vessel, with a height of $7176 \mathrm{~mm}$ and cross-section of $2600 \times 4028 \mathrm{~mm}$. The total residence time of coal in the retort is about 13 hours.

An SJ-type pilot-scale retort was built by SJ Company in 2006 to investigate the suitability of the SJ retort for processing oil shale and lignite as well. In cooperation with SJ Company, the Yaojie Coal Company of Gansu province, China, attempted to use the SJ retort to process YJ oil shale. For testing oil shale samples from Jinhe (JH) and Haikuang (HK) basins of Yaojie county were used.

The SJ pilot-scale retort is a vertical rectangular vessel. Its height is $7176 \mathrm{~mm}$ and cross section $1500 \times 1180 \mathrm{~mm}$. Its daily capacity is 24 tons of oil shale, which is one tenth of the commercial volume. The condensation and recovery systems of the SJ pilot retort are similar to those of the commercial device.

\section{Process scheme used in the SJ-type gas combustion retort}

The retorting process carried out in the SJ-type retort is classified as an internal gas combustion method. Figure 1 shows the flow diagram of the retort. Raw oil shale with a particle size of $8-60 \mathrm{~mm}$ is fed to the top of the 




Fig. 1. Flow diagram of the SJ-type retort.

retort. In the upper section of the retort, oil shale is dried and heated by the ascending hot gases. Heat comes from the combustion of the recycle retorting gas. The temperature of the exiting retorting gas is about $600{ }^{\circ} \mathrm{C}$. The hot gas and oil vapor move directly from the bottom to the top of the retort and then exit through the top. The pyrolysates are shale oil, gas, water and spent shale. After being cooled in the lower part of the retort, spent shale is removed from the retort using a rotating water dish. Unlike the process used in the Fushun retort, spent shale is not burnt in the lower part of the retort [10]. Shale oil is obtained using a condensation unit. Most of the pyrolysis gas is recirculated to the retort.

The operating parameters of the SJ pilot retort for oil shale processing are as follows:

(1) temperature in the pyrolysis section: $550-700{ }^{\circ} \mathrm{C}$, average $610^{\circ} \mathrm{C}$;

(2) temperature of the gas exiting through the top of the retort: 100 $130^{\circ} \mathrm{C}$, average $120^{\circ} \mathrm{C}$;

(3) flow rate of the circulating gas: $700-1000 \mathrm{~m}^{3} / \mathrm{h}$, average $850 \mathrm{~m}^{3} / \mathrm{h}$;

(4) air flow rate: $350-450 \mathrm{~m}^{3} / \mathrm{h}$, average $420 \mathrm{~m}^{3} / \mathrm{h}$;

(5) surplus gas flow rate: $430-800 \mathrm{~m}^{3} / \mathrm{h}$, average $680 \mathrm{~m}^{3} / \mathrm{h}$;

(6) rotating speed of the semicoke removing device: $360-400 \mathrm{r} / \mathrm{min}$;

(7) particle size of oil shale fed: $8-60 \mathrm{~mm}$.

\section{Experimental}

Yaojie oil shale samples from Jinhe (JH) and Haikuang (HK) basins, ten from each, were thoroughly homogenized and crushed to required size. 
The volatiles content of YJ oil shale is $10-60 \%$, that of fixed carbon about $10 \%$, and ash, 30-90\%. The results of Fischer Assay are presented in Table 1.

Table 1. Fischer Assay of Yaojie oil shale (air received basis, ar.,\%)

\begin{tabular}{|c|c|c|c|c|}
\hline Sample & Shale oil, $\%$ & Water, $\%$ & Shale char, $\%$ & Gas and loss, $\%$ \\
\hline JH & 15.11 & 2.64 & 77.22 & 5.03 \\
HK & 10.86 & 1.89 & 83.63 & 3.62 \\
\hline
\end{tabular}

\section{Pilot test results}

\subsection{Material balance}

The material balance for oil shale retorting in the pilot retort is shown in Table 2.

Table 2. Material balance of the pilot test

\begin{tabular}{|c|c|c|c|c|}
\hline Sample & Oil shale, $\mathrm{t}$ & Spent shale, $\mathrm{t}$ & Shale oil, $\mathrm{t}$ & Oil yield*, $\%$ \\
\hline JH oil shale & 53.44 & 42.39 & 7.09 & 86.04 \\
HK oil shale & 64.19 & 54.34 & 5.95 & 84.99 \\
\hline
\end{tabular}

* Oil yield is the percentage of Fischer Assay's.

\subsection{Properties of shale oil}

The properties of the shale oil obtained are presented in Tables 3-5.

\section{Table 3. Properties of shale oil}

\begin{tabular}{|l|c|c|}
\hline \multicolumn{1}{|c|}{ Property } & JH shale oil & HK shale oil \\
\hline Moisture, $\%$ & 0.93 & 0.13 \\
Density, $\mathrm{kg} / \mathrm{m}^{3}$ & 934 & 953 \\
Viscosity, $50{ }^{\circ} \mathrm{C}, \mathrm{mm}^{2} / \mathrm{s}$ & 15.4 & 15.6 \\
Sulfur, \% & 0.54 & 0.53 \\
Carbon residue, \% & 2.03 & 2.03 \\
Flash point, ${ }^{\circ} \mathrm{C}$ & 109 & 108 \\
Pour point, ${ }^{\circ} \mathrm{C}$ & 25 & 30 \\
Mechanical impurities, \% & 0.037 & 0.053 \\
\hline
\end{tabular}

Table 4. SARA analysis of shale oil, $\%$

\begin{tabular}{|c|c|c|c|c|}
\hline Shale oil & Saturates & Aromatics & Resins & Asphaltenes \\
\hline JH & 32.24 & 23.36 & 34.86 & 9.54 \\
HK & 35.91 & 26.51 & 28.18 & 9.40 \\
\hline
\end{tabular}

Table 5. Simulated distillation of shale oil

\begin{tabular}{|c|c|c|c|c|c|}
\hline Shale oil & Initial b.p., ${ }^{\circ} \mathrm{C}$ & Final b.p., ${ }^{\circ} \mathrm{C}$ & Gasoline, $\%$ & Diesel, $\%$ & Residual, $\%$ \\
\hline JH & 165 & 555 & 0.7 & 46 & 53.3 \\
HK & 188 & 561 & 0.0 & 40 & 60.0 \\
\hline
\end{tabular}




\subsection{Calorific value of shale char}

The calorific value of semicoke is given in Table 6 .

Table 6. Calorific value of semicoke (ar., \%)

\begin{tabular}{|c|c|c|}
\hline Semicoke & Calorific value, $\mathrm{kJ} / \mathrm{kg}$ & Calorific value, $\mathrm{kcal} / \mathrm{kg}$ \\
\hline $\mathrm{JH}$ & 7924 & 1895 \\
$\mathrm{HK}$ & 6684 & 1599 \\
\hline
\end{tabular}

\subsection{Compositional analysis of the retorting gas}

The composition of the retorting gas for $\mathrm{HJ}$ and $\mathrm{HK}$ oil shales is presented in Tables 7 and 8, respectively.

Table 7. Composition of the retorting gas for $\mathrm{HJ}$ oil shale

\begin{tabular}{|l|c|c|c|}
\hline \multicolumn{1}{|c|}{ Compound } & $\begin{array}{c}\text { Percentage, } \\
\text { vol. } \%\end{array}$ & $\begin{array}{c}\text { Calorific value, } \\
\mathrm{kJ} / \mathrm{mol}\end{array}$ & $\begin{array}{c}\text { Weighted calorific value, } \\
\mathrm{kJ} / \mathrm{mol}\end{array}$ \\
\hline Nitrogen & 59.45 & 0 & 0.00 \\
Carbon monoxide & 9.01 & 283 & 26.73 \\
Carbon dioxide & 18.42 & 0 & 0.00 \\
Methane & 1.36 & 890 & 12.69 \\
Hydrogen & 11.00 & 285 & 32.96 \\
Ethane & 0.16 & 1560 & 1.31 \\
Acetylene & 0.15 & 1299 & 1.99 \\
Propane & 0.01 & 2220 & 0.14 \\
Ethylene & 0.04 & 1409 & 0.56 \\
Butylene & 0.15 & 2877 & 4.40 \\
n-Butane & 0.11 & 2877 & 3.26 \\
iso-Butane & 0.04 & 2877 & 1.18 \\
Hydrogen sulphide & 0.10 & 1000 & 1.05 \\
\hline
\end{tabular}

Table 8. Composition of the retorting gas for HK oil shale

\begin{tabular}{|l|c|c|c|}
\hline \multicolumn{1}{|c|}{ Compound } & $\begin{array}{c}\text { Percentage, } \\
\text { vol.\% }\end{array}$ & Calorific value, $\mathrm{kJ} / \mathrm{mol}$ & $\begin{array}{c}\text { Weighted calorific value, } \\
\mathrm{kJ} / \mathrm{mol}\end{array}$ \\
\hline Nitrogen & 56.99 & 0 & 0.00 \\
Carbon monoxide & 11.56 & 283 & 32.73 \\
Carbon dioxide & 15.20 & 0 & 0.00 \\
Methane & 2.34 & 890 & 20.80 \\
Hydrogen & 12.78 & 285 & 36.54 \\
Ethane & 0.13 & 1560 & 1.95 \\
Acetylene & 0.45 & 1299 & 5.82 \\
Propane & 0.01 & 2220 & 0.18 \\
Ethylene & 0.05 & 1409 & 0.73 \\
Butylene & 0.22 & 2877 & 6.30 \\
n-Butane & 0.11 & 2877 & 3.30 \\
iso-Butane & 0.05 & 2877 & 1.50 \\
Hydrogen sulphide & 0.13 & 1000 & 2.50 \\
\hline
\end{tabular}


From Tables 7 and 8 it is seen that the average calorific value of the retorting gas for $\mathrm{JH}$ oil shale is $3930 \mathrm{~kJ} / \mathrm{m}^{3}\left(941 \mathrm{kcal} / \mathrm{m}^{3}\right)$ and for $\mathrm{HK}$ oil shale, $5020 \mathrm{~kJ} / \mathrm{m}^{3}\left(1200 \mathrm{kcal} / \mathrm{m}^{3}\right)$. The hydrogen sulfide content of the gases is very high, which is unfavorable from an environmental point of view and the compound needs to be removed before utilization [11].

\section{Conclusions}

1. The oil content of $\mathrm{JH}$ and $\mathrm{HK}$ oil shales is 15.11 and $10.86 \%$, respectively, indicating that the Yaojie oil shale is a valuable resource for production of shale oil.

2. The shale oil yield during the pilot retorting in the SJ retort is about $85 \%$ vs. Fisher Assay, in the Fushun retort, about 65\%.

3. The SJ retort operated smoothly and without failure during the Yaojie oil shale retorting. The heat needed to retort oil shale can be provided by the self-produced retorting gas. Besides, the surplus gas can be used for power generation.

4. The calorific value of semicoke is $1600-1900 \mathrm{kcal} / \mathrm{kg}$. After mixing it with oil shale less than $8 \mathrm{~mm}$ in particle size, semicoke can be used for power generation, employing the circulating fluidized-bed boiler.

5. Oil shale ash can be utilized for the production of cement and other building materials.

\section{Acknowledgements}

We acknowledge the financial support from the Taishan Mountain Scholar Constructive Engineering Foundation of Shandong province, China (No.ts20120518), and the Science Foundation of China University of Petroleum, Beijing, China (No.KYJJ2012-06-32).

\section{REFERENCES}

1. Hakala, J. A., Stanchina, W., Soong, Y., Hedges, S. Influence of frequency, grade, moisture and temperature on Green River oil shale dielectric properties and electromagnetic heating processes. Fuel Process. Technol., 2011, 92(1), $1-12$.

2. Li, S. Y., Ma, Y., Qian, J. L. Chinese current oil shale business. In: Proc. 31th Oil Shale Symposium. Colorado School of Mines, Golden, Colorado, USA, Oct. 17-21, 2011.

3. Huo, X. L. Shale Oil Industry in China. China Petrochemical Press, Beijing, 1986 (in Chinese).

4. Qian, J. L. Oil Shale-Petroleum Alternatives. China Petrochemical Press, Beijing, 2010. 
5. Purga, J. Today's Rainbow ends in Fushun. Oil Shale, 2004, 21(4), 269-272.

6. Yin, L. Current status of oil shale industry in Fushun, China. International Oil Shale Conference: "Recent Trends in Oil Shale", 7-9 November 2006, Amman, Jordan. Nov. 7-9, 2006, paper No. rtos-A106.

7. Dung, N. V. A new concept for retorting oil shales. Fuel, 1987, 66(3), 377-383.

8. Burnham, A. K., McConaghy, J. R. Comparison of the acceptability of various oil shale processes. In: Proc. 26th Oil Shale Symposium. Colorado School of Mines, Golden, Colorado, USA, 16-19 October, 2006.

9. Wang, S., Jiang, X. M., Han, X. X., Tong, J. H. Investigation of Chinese oil shale resources comprehensive utilization performance. Energy, 2012, 42(1), 224-232.

10. Qian, J. L., Wang, J. Q. Oil shale activity in China. In: Proc. 26th Oil Shale Symposium. Colorado School of Mines, Golden, Colorado, USA, 16-19 October, 2006.

11. Williams, P. F. V. Oil shales and their analysis. Fuel, 1983, 62(7), 756-771.

Received April 7, 2012 